\title{
GENETIC SELECTION OF Pinus taeda L. THROUGH MULTI- ENVIRONMENT TRIAL
}

\author{
Vanessa Ishibashi ${ }^{1 *}$, Paulo César Flores Junior ${ }^{2}$, Diego Tyszka Martinez ${ }^{3}$, Antonio Rioyei Higa ${ }^{4}$ \\ 1*Universidade Federal do Paraná, Departamento de Ciências Florestais, Curitiba, PR, Brasil - vanessa.ishibashi@gmail.com \\ ${ }^{2}$ Universidade Federal Rural da Amazônia, Campus Belém, Belém, PA, Brasil - paulocesarfloresjunior@gmail.com \\ ${ }^{3}$ Universidade Federal do Paraná, Curitiba, PR, Brasil - diegotyszka@ hotmail.com \\ ${ }^{4}$ Universidade Federal do Paraná, Curitiba, PR, Brasil - antonio.higa@ gmail.com \\ Received for publication on: 18/07/2019 - Accepted for publication on: 02/07/2020
}

\begin{abstract}
Resumo
Seleção genética de Pinus taeda L. em ensaio multi-ambiente. O objetivo do trabalho foi selecionar progênies de Pinus taeda em ensaio multi-ambiente, para formação de pomares clonais de sementes, visando avanço nas gerações do programa de melhoramento genético. Analisou-se um teste de progênies com 53 famílias de polinização aberta, plantado em quatro diferentes locais, em delineamento de blocos casualizados, com sete repetições e parcelas lineares de seis plantas. Foi realizada a mensuração direta da variável DBH aos nove anos de idade. Todas as estimativas foram realizadas utilizando o software Selegen REML/BLUP®. Foi detectada interação genótipo x ambiente, sendo necessária a definição de duas zonas de melhoramento para minimizar os efeitos da dessa interação. A base genética da população estudada é restrita, assim as famílias foram distribuídas em nove grupos distintos pela análise de divergência genética e agrupamento pelo método de Tocher pelas distâncias de Mahalanobis. Com base nos resultados, conclui-se que a estratégia de seleção indicada, considerando o equilíbrio entre manutenção de variabilidade e ganhos genéticos, é a formação de pomares clonais de sementes com 50 indivíduos, com restrição de indivíduos por família. A realização de cruzamentos intraespecíficos entre famílias divergentes pode ser utilizada para aumento da heterose e da variabilidade genética na população estudada.
\end{abstract}

Palavras chave: DAP; produção de sementes; agrupamento; variabilidade

\begin{abstract}
The aim of this study is to select progenies of Pinus taeda through multi-environmental trial to establish clonal seed orchards and advance breeding-program generations. Progeny test was carried out with 53 open-pollinated families planted in four different locations. The study followed a randomized block statistical design, with seven replications in linear plots planted with six plants each. DBH variable was measured in individuals at the age of nine years. All estimates were carried out in Selegen REML/BLUP® software. Genotype x environment interaction was detected; therefore, it required the definition of two breeding zones to minimize its effects. The genetic basis of the assessed population is restricted. Families were distributed into nine different groups, based on genetic divergence analysis, and grouping through the Tocher method, by using Mahalanobis distances. Based on the results, and by taking into consideration the balance between variability maintenance and genetic gains, it is recommended to establish a clonal seed orchard with 50 selected individuals in the experiment, based on a limited number of individuals per family. Intraspecific crossing between divergent families can also be used to increase heterosis and genetic variability in the assessed population.

Keywords: DBH; seed production; grouping; variability
\end{abstract}

\section{INTRODUCTON}

Pinus spp. plantations cover 1.6 million hectares in Brazil, mainly in Paraná (42\%) and Santa Catarina (34\%) states, mostly because of the soil and climate conditions in this region and the location of the main processing industries that use this type of wood. Pinus taeda Linnaeus is the most important coniferous used for commercial purposes in Brazil, mainly for softwood pulp production, sawmill and venners. There are approximately 1 million hectares planted with it and its mean yield reaches $30.5 \mathrm{~m}^{3} \mathrm{ha}^{-1}$ year $^{-1}$ (IBÁ, 2017).

Most $P$. taeda plantations in Brazil are originated from seedlings; thus, breeding programs are set to produce genetically improved seeds in seed orchards. Therefore, the genetic selection of individuals and use of the best silvicultural techniques are essential to get high productivity in multi-environmental situations (DIAS et al., 2018; DVORAK, 2012).

Selection of genotypes in different locations is affected by the genotype $\mathrm{x}$ environment interaction, which is assessed through multi-environment trials. The target selected population should have all the likely genotypes expected to best develop and grow in the set of target environments, which can be defined based on geography, soil and meteorological conditions, management options and on the incidence of biotic and abiotic stress (ELIAS et al., 2016). 
Analysis applied to the multi-environment trial allowed elaborating recommendations and genetic selection strategies, and the conservation of genetic variability (CORREIA et al., 2010). Different breeding strategies must be adopted to explore significant genotype $\mathrm{x}$ environmental interaction, in order to take advantage of its positive effects on each environment. One single breeding zone can be defined, in case of no significant genotype $\mathrm{x}$ environmental interaction, in order to meet the demand for seeds in all tested environments (MARTINEZ et al., 2012). Significant genotype $\mathrm{x}$ environment interactions for $P$. taeda were found by Paludzyszyn Filho et al. (2001), in half-sib progenies, and by Dias et al. (2018) in test based on using clones obtained through somatic embryogenesis. Martinez et al. (2012) did not detect significant genotype $\mathrm{x}$ environmental interaction between half-sib progenies, in a progeny trial with $P$. taeda.

Genetic diversity between genotypes integrating a seed orchard is essential to increase the frequency of desirable alleles in the breeding population (JOHNSON et al., 2001) and to cope with climate change predictions (DVORAK, 2012), as well as the continuity of breeding programs aiming at producing seeds for new planting sites.

Based on the hypothesis that there is significant genotype $\mathrm{x}$ environment interaction in $P$. taeda - what has implications in the genotype selection strategy -, the aim of this study was to select $P$. taeda progenies through multi-environment trial to establish clonal seed orchards and advanced generations for it.

\section{MATERIALS AND METHODS}

Experimental sites are located in Santa Catarina State highlands, in Rio Negrinho (locations A, B and C) and Lages (Location D) municipalities. Climate in the region is classified as Cfb, subtropical humid, based on Köppens' classification: mild summer, without dry season (ALVARES et al., 2013). Rio Negrinho records mean rainfall of $1,876 \mathrm{~mm}$, minimum temperature of $13.2^{\circ} \mathrm{C}$, mean temperature of $18.3^{\circ} \mathrm{C}$ and maximum temperature of $22.1^{\circ} \mathrm{C}$. Lages presents mean rainfall of $1,854 \mathrm{~mm}$, minimum temperature of $11.6^{\circ} \mathrm{C}$, mean temperature of $16.1^{\circ} \mathrm{C}$ and maximum temperature of $21.2^{\circ} \mathrm{C}$.

Soil in location A was classified as Haplic Cambisol; altitude in this location was $852 \mathrm{~m}$. It presents wavy smooth topography. Soil in location B was classified as Haplic Cambisol; altitude in this location was $830 \mathrm{~m}$. It presents very slopped topography. Soil in location C was classified as Humic Cambisol and its altitude was 886 $\mathrm{m}$; it presented slopped topography. Soil in location D was classified as Humic Cambisol and its altitude was 895 $\mathrm{m}$; it presents very slopped topography.

The genetic material of $P$. taeda came from a $1^{\text {st }}$ generation clonal seed orchard (CSO); its material originated from Florida, Louisiana, and Georgia (USA); it came from a seed producer area (SPA) established with seeds from Zimbabwe provenance. The open pollination progeny test was planted in four different environments (Locations A, B, C and D), it followed a randomized block design with 53 families, 7 replications per location, in row plots with six plants each - planting spacing was $2.5 \mathrm{~m} \mathrm{x} 2.0 \mathrm{~m}$-; trial double border was adopted. The variable "diameter at breast height (DBH)" was evaluated at the age of nine years.

\section{Estimates of genetic parameters}

Individual BLUP for DBH was estimated in the SELEGEN - REML/BLUP ® software, based on model:

$$
y=X r+Z a+W p+\varepsilon
$$

wherein, $y$ is the data vector, $r$ is the value of block effects (assumed as fixed) summed to the general average, $a$ is the vector of individual genetic additive effects (assumed as random), $p$ is the vector of the effects of the partitions (assumed as random) and $\varepsilon$ is the vector of errors or residues (random). Lowercase letters represent the incidence matrices of the referred effects (RESENDE, 2016).

The following model was used for the selection process in the four locations (joint analysis):

$$
y=X r+Z a+W p+T i+\varepsilon
$$

wherein, $y$ is data vector, $r$ is the vector of the block effects (assumed as fixed) summed to the general average, $a$ is the vector of the individual genetic additive effects (assumed as random), $p$ is the vector of partition effects (assumed as random), $i$ is the vector of the genotype $\mathrm{x}$ environment interaction effects (random) and $\varepsilon$ is the vector of errors or residues (random). Lowercase letters represent the incidence matrices of the referred effects (RESENDE, 2016).

The structures and distribution of means and variance, the mix model equations, the REML estimators and the restricted probability function associated with the random effects were based on Resende (2016).

Mahalanobis statistical distance values at genotypic level and grouping through the Tocher method were calculated in SELEGEN REML/BLUP® software (RESENDE, 2007).

FLORESTA, Curitiba, PR, v. 51, n. 1, p. 211-219, jan/mar 2021.

Ishibashi, V. et.al.

ISSN eletrônico 1982-4688

DOI: $10.5380 /$ rf.v51 i1. 68057 


\section{Clonal seed orchard establishment}

BLUP values found through joint analysis were used to select trees for clonal seed orchard (CSO) establishment. In total, the 50 best individuals with the highest individual genetic values $\left(a_{s}\right)$ for DBH, without limiting maximum number of individuals per family, and with selection of five, four, three, two and one individual per family, were selected.

\section{Effective population size ( $\mathrm{Ne}$ ), inbreeding coefficient and genetic gain}

The following expression was used to calculate the effective population size (RESENDE, 2015):

$$
N e=\left(4 \times N_{f} \times K_{f}\right) /\left(K_{f}+3+\left(\sigma_{K f}^{2} / K_{f}\right)\right)
$$

wherein, $N_{f}$ is the number of selected families, $K_{f}$ is the mean number of individuals selected per family and $\sigma^{2}{ }_{k f}$ is the variance in the number of selected individuals per family.

Inbreeding coefficient was calculated through equation:

$$
F=1 /(2 \times N e)
$$

Genetic gain calculation was carried out based on equation:

$$
\left.G_{\%}=\left(\overline{a_{s}}\right) / \bar{x}\right) \times 100
$$

wherein, $\overline{a_{s}}$ is the mean genetic value recorded for the selected individuals and $\bar{x}$ is the average recorded for the test.

\section{RESULTS}

Locations A, C and D presented similar DBH growth, whereas location B presented the lowest growth rate. Locations $\mathrm{A}$ and $\mathrm{D}$ showed partition effects determination coefficient ( $\mathrm{c}^{2}$ parc) for DBH higher than $10 \%$ (TABLE 1$)$ and low additive genetic variance $\left(\hat{\sigma}_{\mathrm{a}}^{2}\right)$. This outcome led to low individual genetic additive variation coefficient values $\left(\mathrm{CV}_{\mathrm{gi}}\right)$ (TABLE 1$)$.

Relative variation coefficient $\left(\mathrm{Cv}_{\mathrm{r}}\right)$ was higher in locations B and $\mathrm{C}(0.60$ and 0.62$)$ and lower in locations $A$ and $\mathrm{D}(0.39$ and 0.30$)$ (TABLE 1$)$. Heritability, in the strict sense $\left(\mathrm{h}^{2}{ }_{\mathrm{a}}\right.$ ), ranged from 0.12 (location $\left.\mathrm{D}\right)$ to 0.27 (location C) (TABLE 1).

Location D presented the lowest standard deviation for the predicted genotypic value of progenies (SEP) (0.25). The highest values were recorded for locations B (0.44) and C (0.47) (TABLE 1). Figure 1 shows the amplitude of predicted genetic additive values and the different performances of progenies in the four locations; it indicates the presence of genotype $\mathrm{x}$ environment interaction.

Table 1 - Variance components and genetic parameters for DBH in progeny test applied to $P$. taeda at the age of nine years grown in four locations in Santa Catarina State, based on individual analysis.

Tabela 1 - Componentes de variância e parâmetros genéticos para DAP em teste de progênies de $P$. taeda aos nove anos de idade plantado em quatro locais no estado de Santa Catarina pela análise individual.

\begin{tabular}{lrrrr}
\hline \multicolumn{1}{c}{$\begin{array}{c}\text { Parameter/ } \\
\text { Location }\end{array}$} & \multicolumn{4}{c}{ DBH } \\
\cline { 2 - 5 } & $\mathrm{A}$ & $\mathrm{B}$ & $\mathrm{C}$ & $\mathrm{D}$ \\
\hline$\hat{\sigma}_{\mathrm{a}}{ }_{\mathrm{a}}$ & 0.81 & 2.72 & 3.20 & 0.38 \\
$\hat{\sigma}_{\text {parc }}{ }^{2}$ & 0.67 & 0.15 & 0.32 & 0.75 \\
$\hat{\sigma}_{\mathrm{e}}$ & 3.31 & 8.40 & 8.41 & 1.98 \\
$\hat{\sigma}_{\mathrm{f}}$ & 4.79 & 11.27 & 11.93 & 3.11 \\
$\mathrm{~h}^{2}{ }_{\mathrm{a}}$ & $0.17 \pm 0.05$ & $0.24 \pm 0.07$ & $0.27 \pm 0.07$ & $0.12 \pm 0.05$ \\
$\mathrm{~h}^{2}{ }_{\mathrm{ajus}}$ & 0.20 & 0.24 & 0.28 & 0.16 \\
$\mathrm{c}^{2}{ }_{\mathrm{parc}}$ & 0.14 & 0.01 & 0.03 & 0.24 \\
$\mathrm{~h}^{2}{ }_{\mathrm{mp}}$ & 0.52 & 0.72 & 0.73 & 0.34 \\
$\mathrm{Ac}_{\text {prog }}$ & 0.72 & 0.85 & 0.85 & 0.58 \\
$\mathrm{~h}^{2}{ }_{\mathrm{ad}}$ & 0.16 & 0.20 & 0.22 & 0.13 \\
$\mathrm{CV}_{\mathrm{gi} \%}$ & 4.51 & 9.13 & 9.29 & 3.17
\end{tabular}

FLORESTA, Curitiba, PR, v. 51, n. 1, p. 211-219, jan/mar 2021.

Ishibashi, V.et.al.

ISSN eletrônico 1982-4688

DOI: 10.5380/rf.v51 i1. 68057 


\begin{tabular}{lrrrr}
$\mathrm{CV}_{\mathrm{gp} \%}$ & 2.26 & 4.57 & 4.65 & 1.58 \\
$\mathrm{CV}_{\mathrm{e} \%}$ & 5.77 & 7.61 & 7.56 & 5.47 \\
$\mathrm{CV}_{\mathrm{r}}$ & 0.39 & 0.60 & 0.62 & 0.29 \\
$\mathrm{PEV}$ & 0.10 & 0.19 & 0.22 & 0.06 \\
$\mathrm{SEP}$ & 0.31 & 0.44 & 0.47 & 0.25 \\
$\mu$ & 19.96 & 18.04 & 19.25 & 19.38 \\
\hline
\end{tabular}

wherein: $\hat{\sigma}_{\mathrm{a}}^{2}$ : genetic additive variance; $\hat{\sigma}_{\text {parc }}^{2}$ environmental variance between partitions; $\hat{\sigma}_{\mathrm{e}}^{2}$ : residual variance within the partition (environmental + genetic non-additive); $\hat{\sigma}_{\mathrm{f}}{ }^{2}$ individual phenotypic variance; $\mathrm{h}_{\mathrm{a}}^{2}$ : individual heritability in the strict sense; $\mathrm{h}^{2}{ }_{\text {ajus}}$ : individual heritability in the strict sense, adjusted to partition effects; $\mathrm{c}^{2}$ parc: coefficient of determination of partition effects; $\mathrm{h}^{2} \mathrm{mp}$ : mean heritability of the progeny; $\mathrm{Ac}_{\text {prog: }}$ accuracy of progeny analysis; $\mathrm{h}_{\text {ad: }}^{2}$ : additive heritability within the partition; $\mathrm{CV}_{\mathrm{gi} \%}$ : individual genetic additive variation coefficient; $\mathrm{CV}_{\mathrm{gp} \%}$ : genotypic variation coefficient between progenies; $\mathrm{CV}_{\mathrm{e}}$ : residual variation coefficient; $\mathrm{CV}_{\mathrm{r}}$ : relative variation coefficient; PEV: prediction error variance of progenies' genotypic values, by assuming full survival; SEP: standard deviation of the predicted progeny genotypic value; $\mu=$ general mean of the experiment.

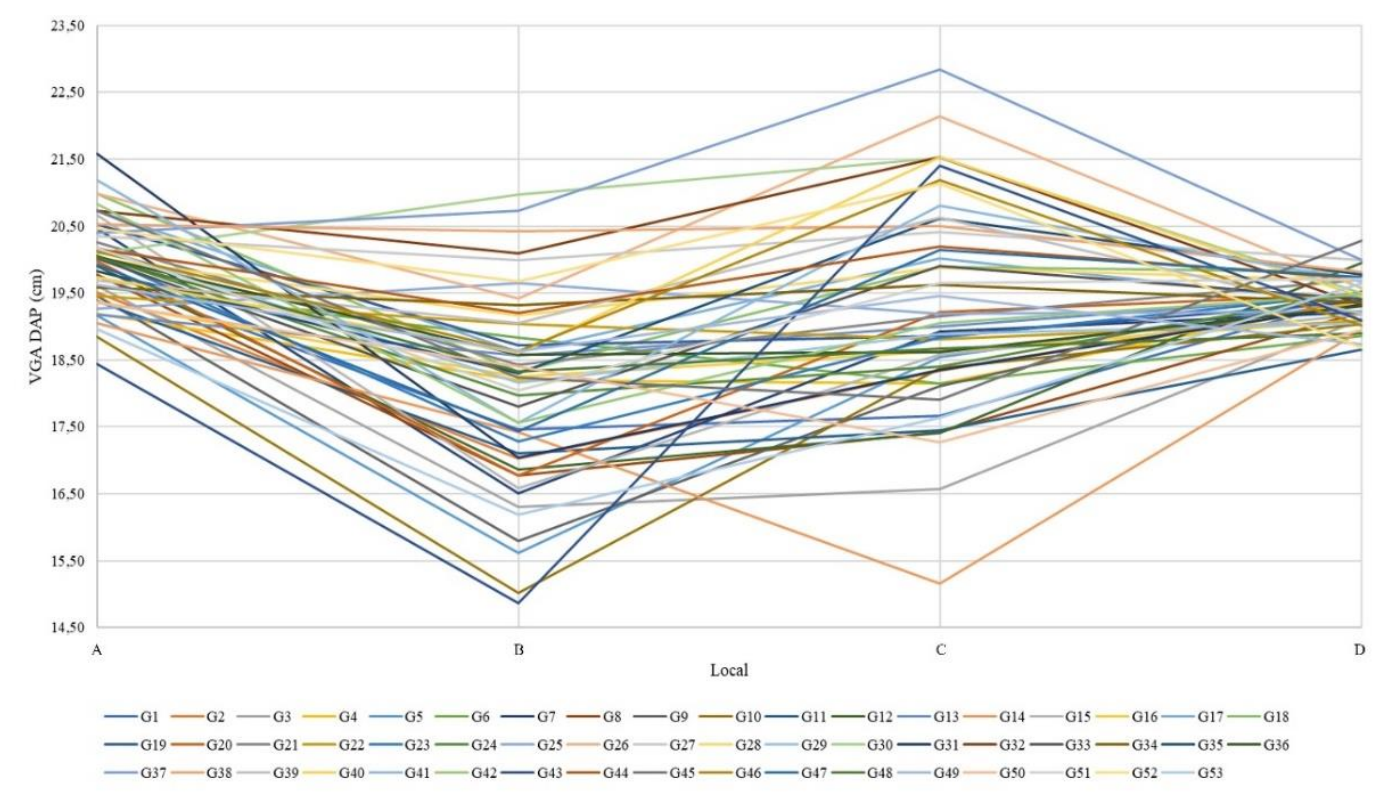

Figure 1 - Behavior of the 53 half-sib families of $P$. taeda recorded for genetic additive value (DBH) in individuals at the age of nine years in progeny test planted in four different locations in Santa Catarina State

Figura 1 - Comportamento das 53 famílias de meio-irmãos de P. taeda, para valor genético aditivo para DAP, aos nove anos de idade em teste de progênies plantado em quatro locais no estado de Santa Catarina

Genotype $\mathrm{x}$ environment interaction was assessed through joint analysis by taking into account all locations and their conditions. The determination of low coefficients of genotype $\mathrm{x}$ environment interaction effects $\left(\mathrm{c}^{2}\right.$ int $)$ explain the low rate of total phenotypic variance $\left(\widehat{\boldsymbol{\sigma}}_{\mathrm{f}}\right)$ recorded for all combinations of locations. Therefore, these outcomes led to low genotypic correlation values between locations $\left(\mathrm{rg}_{\mathrm{loc}}\right)$ in combinations C-D $(0.33)$ and B-D (0.24), to moderate values in the analysis of the four locations $(0.53)$ in combinations A-D $(0.51), \mathrm{A}-\mathrm{C}(0.50)$, A-B-C (0.61), A-B-D (0.46), B-C-D (0.52) and A-C-D (0.48), as well as to high values in A-D (0.82) and B-C (0.75). These findings are indicative of the need of defining two breeding zones (TABLE 2).

Except for combinations B-D, C-D and A-B-D, individual heritability values $\left(\mathrm{h}^{2}\right)$ were equal to, or higher than $10 \%$. The highest genetic additive variance value $\left(\hat{\sigma}_{\mathrm{a}}^{2}\right)$ was recorded for combination $\mathrm{B}-\mathrm{C}$, as well as the lowest individual heritability value $\left(\mathrm{h}^{2}{ }_{\mathrm{a}}\right)$. Heritability at mean families $\left(\mathrm{h}^{2}{ }_{\mathrm{mp}}\right)$ and selective accuracy level $\left(\mathrm{Ac} \mathrm{c}_{\mathrm{prog}}\right)$ were high, except for B-D and C-D (TABLE 2).

Table 2 - Components of variance and genetic parameters set for DBH in P. taeda progeny test, in individuals at the age of nine years, grown in four different locations in Santa Catarina State, based on joint analysis.

Tabela 2 - Componentes de variância e parâmetros genéticos para DAP em teste de progênies aos nove anos de idade de $P$. taeda plantado em quatro locais no estado de Santa Catarina pela análise conjunta. 


\begin{tabular}{|c|c|c|c|c|c|c|c|c|c|c|c|}
\hline & All & A-B & A-C & A-D & B-C & B-D & C-D & A-B-C & A-B-D & B-C-D & A-C-D \\
\hline$\hat{\sigma}^{2}$ & 0.93 & 0.89 & 0.98 & 0.51 & 2.21 & 0.38 & 0.60 & 1.34 & 0.60 & 1.09 & 0.70 \\
\hline$\hat{\sigma}^{2}$ parc & 0.44 & 0.38 & 0.50 & 0.70 & 0.21 & 0.38 & 0.51 & 0.36 & 0.48 & 0.36 & 0.57 \\
\hline$\hat{\sigma}^{2}{ }_{\text {int }}$ & 0.21 & 0.21 & 0.25 & 0.03 & 0.18 & 0.30 & 0.30 & 0.22 & 0.18 & 0.25 & 0.19 \\
\hline$\hat{\sigma}^{2}{ }_{\mathrm{e}}$ & 6.34 & 6.60 & 6.59 & 2.76 & 8.98 & 6.46 & 6.34 & 7.41 & 5.32 & 7.30 & 5.25 \\
\hline$\hat{\sigma}^{2}$ & 7.92 & 8.08 & 8.32 & 4.01 & 11.59 & 7.52 & 7.75 & 9.33 & 6.58 & 9.01 & 6.71 \\
\hline $\mathrm{h}^{2}{ }_{\mathrm{a}}$ & $\begin{array}{r}0.12 \\
\pm 0.02\end{array}$ & $\begin{array}{r}0.11 \\
\pm 0.03\end{array}$ & $\begin{array}{r}0.12 \\
\pm 0.03\end{array}$ & $\begin{array}{r}0.13 \\
\pm 0.03\end{array}$ & & $\begin{array}{r}0.05 \\
\pm 0.02\end{array}$ & $\begin{array}{r}0.08 \\
\pm 0.03\end{array}$ & & & $\begin{array}{r}0.12 \\
\pm 0.03\end{array}$ & $\begin{array}{r}0.10 \\
\pm 0.02\end{array}$ \\
\hline$c^{2}$ parc & 0.06 & 0.05 & 0.06 & 0.18 & 0.02 & 0.05 & 0.07 & 0.04 & 0.07 & 0.04 & 0.09 \\
\hline$c^{2}$ int & 0.03 & 0.03 & 0.03 & 0.01 & 0.02 & 0.04 & 0.04 & 0.02 & 0.03 & 0.03 & 0.03 \\
\hline $\mathrm{h}^{2}{ }_{\mathrm{mp}}$ & 0.68 & 0.50 & 0.50 & 0.54 & 0.70 & 0.27 & 0.35 & 0.68 & 0.54 & 0.62 & 0.55 \\
\hline $\mathrm{Ac}_{\mathrm{prog}}$ & 0.82 & 0.71 & 0.70 & 0.73 & 0.84 & 0.52 & 0.59 & 0.83 & 0.73 & 0.78 & 0.74 \\
\hline $\mathrm{h}^{2}{ }_{\mathrm{ad}}$ & 0.10 & 0.09 & 0.10 & 0.12 & 0.16 & 0.04 & 0.07 & 0.12 & 0.08 & 0.10 & 0.09 \\
\hline $\mathrm{rg}_{\mathrm{loc}}$ & 0.53 & 0.51 & 0.50 & 0.82 & 0.75 & 0.24 & 0.33 & 0.61 & 0.46 & 0.52 & 0.48 \\
\hline PEV & 0.08 & 0.11 & 0.12 & 0.06 & 0.16 & 0.07 & 0.10 & 0.11 & 0.07 & 0.11 & 0.08 \\
\hline SEP & 0.28 & 0.33 & 0.35 & 0.24 & 0.41 & 0.26 & 0.31 & 0.33 & 0.26 & 0.32 & 0.28 \\
\hline$\mu$ & 19.16 & 19.02 & 19.61 & 19.69 & 18.66 & 18.71 & 19.32 & 19.10 & 19.14 & 18.88 & 19.54 \\
\hline
\end{tabular}

Wherein: $\hat{\sigma}_{\mathrm{a}}^{2}$ : genetic additive variance; $\hat{\sigma}^{2}{ }_{\text {parc }}$ : environmental variance between partitions; $\hat{\sigma}^{2}{ }_{\text {int }}$ : genotype $\mathrm{x}$ environment interaction variance; $\hat{\sigma}_{\mathrm{e}}^{2}$ : residual variance within the partition (environmental + genetic non-additive); $\hat{\sigma}_{\mathrm{f}}^{2}$ : individual phenotypic variance; $\mathrm{h}_{\mathrm{a}}^{2}$ : individual heritability in the strict sense; $\mathrm{c}^{2}$ parc : coefficient of determination of partition effects; $\mathrm{c}^{2}{ }_{\text {int }}$ : coefficient of determination of genotype $\mathrm{x}$ environment interaction effects; $\mathrm{h}^{2}{ }_{\mathrm{mp}}$ : mean heritability of progenies; $A \mathrm{c}_{\text {prog }}$ : accuracy of progeny selection; $\mathrm{h}^{2}{ }_{\text {ad }}$ : additive heritability within the partition; $\mathrm{rg}_{\text {loc }}$ : genetic correlation between locations; PEV: variance of prediction error of progenies' genotypic values by assuming full survival; SEP: standard deviation of predicted progenies' genotypic values by assuming full survival; $\mu=$ general mean of the experiment.

The selection of the 50 best individuals to set the clonal seed orchards for the two breeding zones,-only took into consideration locations that have presented high genetic correlation. Selection without restrictions of number of individuals per family, which was set for combination A-D, resulted in $4.1 \%$ genetic gain. However, the effective population size, and the inbreeding coefficient associated with seeds produced in the orchard, recorded 19.3 and 2.6, respectively. The largest effective population size was found through restriction, by selecting one individual per family. This process reduced genetic gain to $2.7 \%$ in relation to the other simulations set for combination A-D (TABLE 3). The selection for 3 individuals per family, maximum, showed genetic gain of $3.8 \%$. This process did not have strong impact on the DAP average for the next generation, increased the effective size of the population and reduced the inbreeding coefficient in relation to selection without optimizing the number of individuals per family (TABLE 3 ).

Similar association between genetic gains and effective population size was observed in combination B-C, whose genetic higher gain was found when there was no restriction in the number of individuals per family (11.4\%). The lowest gain was found by limiting the number of individuals to 1 per family (6.7\%). Selection with at most four individuals per family was advantageous, since it resulted in more than $100 \%$ increase in the effective size of the population and reduced inbreeding coefficient, at this same rate, in relation to selection without optimizing the number of individuals per family (TABLE 3 ).

Table 3 - Genetic gain and effective population size based on selection through joint analysis applied to variable DBH in P. taeda grown in Santa Catarina State for clonal seed orchard formation - 50 individuals were selected.

Tabela 3 - Ganho genético, tamanho efetivo populacional com a seleção pela análise conjunta para a variável DAP em $P$. taeda no estado de Santa Catarina para formação de pomar clonal de sementes com 50 indivíduos. 


\begin{tabular}{lcccccccccc}
\hline & \multicolumn{1}{c}{ SCO } & \multicolumn{1}{c}{ Locations } & \multicolumn{1}{c}{ Locations B-C } \\
\cline { 2 - 10 } & $\mathrm{G}$ & $\mathrm{G} \%$ & $\mu \mathrm{M}$ & $\mathrm{Ne}$ & $\mathrm{F}$ & $\mathrm{G}$ & $\mathrm{G} \%$ & $\mu \mathrm{M}$ & $\mathrm{Ne}$ & $\mathrm{F}$ \\
\hline No restriction & 0.8 & 4.1 & 20.5 & 19.3 & 2.6 & 2.1 & 11.4 & 20.8 & 12.1 & 4.1 \\
CSO-5 & 0.8 & 4.0 & 20.5 & 27.5 & 1.8 & 2.0 & 10.5 & 20.6 & 26.8 & 1.9 \\
CSO -4 & 0.8 & 4.0 & 20.5 & 30.7 & 1.6 & 1.9 & 10.2 & 20.6 & 30.3 & 1.6 \\
CSO -3 & 0.8 & 3.8 & 20.5 & 36.4 & 1.4 & 1.8 & 9.7 & 20.5 & 36.4 & 1.4 \\
CSO -2 & 0.7 & 3.6 & 20.4 & 41.3 & 1.2 & 1.7 & 8.9 & 20.3 & 42.0 & 1.2 \\
CSO -1 & 0.5 & 2.7 & 20.2 & 50.0 & 1.0 & 1.2 & 6.7 & 19.9 & 50.0 & 1.0 \\
\hline
\end{tabular}

wherein: G: genetic gain $(\mathrm{cm}) ; \mathrm{G}_{\%}$ : genetic gain rate; Ne: effective population size; F: inbreeding coefficient; $\mu_{\mathrm{M}}$ : improved mean; CSO-5: clonal seed orchards with at most five individuals per family; CSO -4: Clonal seed orchard with at most four individuals per family; CSO -3: Clonal seed orchard with at most three individual per family; CSO -2: clonal seed orchard with at most two individuals per family; CSO -1: clonal seed orchard with at most one individual per family.

Families, both in combination A-D and B-C, were divided into nine different groups based on genetic divergence analysis and on grouping by Tocher test, according to Mahalanobis Distances (TABLE 4).

It is recommended to generate intra-specific hybrids through controlled crossing between the most divergent and productive families in order to explore potential heterosis. In case of CSO-3 - which could be established by using genetically selected individuals in locations A and D -, it is recommended to have controlled crossing between individuals from families 51 and 47 with progenies of families in groups II and V (TABLE 4). These progenies are among families recording the highest predicted genetic values for DBH. For CSO-4 formed for sites B and C, the most divergent crosses are between progenies of families 31 and 42 and the one of families in groups I, IV, V and VI (TABLE 4).

Table 4 - $P$. taeda grouping (Tocher) based on Mahalanobis distances applied to variable DBH and found through joint analysis of progeny test evaluated at locations A and D, and B and C, in Santa Catarina State.

Tabela 4 - Agrupamento (Tocher) pelas distâncias de Mahalanobis em $P$. taeda envolvendo a variável DAP pela análise conjunta de um teste de progênies avaliado nos locais A e D e nos locais B e C no estado de Santa Catarina.

\begin{tabular}{|c|c|c|c|c|c|c|c|c|c|c|c|c|c|c|c|c|}
\hline \multicolumn{17}{|c|}{ Locations A-D } \\
\hline Group & \multicolumn{16}{|c|}{ Families } \\
\hline I & 6 & 10 & 11 & 14 & 55 & 56 & & & & & & & & & & \\
\hline II & 7 & 12 & 15 & 18 & 20 & 21 & & 22 & 24 & 25 & 31 & 33 & 35 & 40 & $50 \quad 53$ & 57 \\
\hline III & 2 & 3 & 4 & 5 & 8 & 9 & & 13 & 32 & 39 & 44 & 52 & 54 & 61 & 63 & \\
\hline IV & 16 & 23 & 26 & & & & & & & & & & & & & \\
\hline V & 19 & 27 & 29 & 34 & 42 & 43 & & 46 & & & & & & & & \\
\hline VI & 1 & 36 & 41 & 45 & & & & & & & & & & & & \\
\hline VII & 47 & & & & & & & & & & & & & & & \\
\hline VIII & 48 & & & & & & & & & & & & & & & \\
\hline IX & 51 & & & & & & & & & & & & & & & \\
\hline \multicolumn{17}{|c|}{ Locations B-C } \\
\hline Group & & ilies & & & & & & & & & & & & & & \\
\hline I & 4 & 6 & 16 & 21 & 24 & 25 & & 32 & 41 & 47 & 48 & 51 & 54 & 56 & & \\
\hline II & 5 & 8 & 9 & 10 & 11 & 12 & & 63 & & & & & & & & \\
\hline III & 1 & 2 & 7 & 15 & 34 & & & & & & & & & & & \\
\hline IV & 13 & 18 & 19 & 20 & 22 & 23 & & 26 & 36 & 39 & 40 & 46 & 53 & 55 & 57 & \\
\hline V & 29 & 43 & 44 & 45 & 50 & 52 & & 61 & & & & & & & & \\
\hline VI & 27 & 33 & 35 & & & & & & & & & & & & & \\
\hline VII & 3 & 14 & & & & & & & & & & & & & & \\
\hline VIII & 31 & & & & & & & & & & & & & & & \\
\hline IX & 42 & & & & & & & & & & & & & & & \\
\hline
\end{tabular}

Note: Emphasis on families selected for clonal orchard formation

FLORESTA, Curitiba, PR, v. 51, n. 1, p. 211-219, jan/mar 2021.

Ishibashi, V. et.al.

ISSN eletrônico 1982-4688

DOI: $10.5380 /$ rf.v51 i1. 68057 


\section{DISCUSSION}

Two locations have shown effects of determination coefficient of plots higher than the recommend by Sturion and Resende (2005). These authors classified values lower than $10 \%$ as low, it indicates that plot disposition in these blocks is not homogeneous in these locations. However, the experimental variation coefficient for DBH was lower than $8 \%$ in all locations (TABLE 1), and this finding is indicative of good experimental precision (MARTINEZ et al., 2012). It also enables accurate inferences through progeny test evaluation.

The observed genotype $\mathrm{x}$ environment pattern may have several causes. However, the herein observed variation in soil properties, due to topography, seemed to have played important role in the differentiated performance of genotypes. It is so, because one of the breeding zones was set based on the combination of trials in different counties (locations A and D), and because the correlation of genetic performance recorded for progenies in locations in Rio Negrinho Municipality (Locations A, B and C) was moderate. Lower tree growth in locations recording higher declivity may have contributed to soil physical and chemical differences caused by the slope topography, as also highlighted by Gomes et al. (2016), Ruiz et al. (2016) and Horst et al. (2018) for $P$. taeda. The most slopped sites should present lower DBH growth potential because they favor water and nutrient exportation from the system (RUIZ et al., 2016).

Thus, declivity can work as selection agent, since these locations were more discriminatory in genotype distinction and presented higher genetic additive variability. This finding points towards phenotypic plasticity differences in genetic control, which represents adaptive response to environmental heterogeneity (CORREIA $e t$ al., 2010).

However, such an interaction can be more complex, because, despite the soil and climate factors, it can be related to origin, provenance, genetic material propagation form, among other factors. Dias et al. (2018) carried out a clonal test with $P$. taeda, in individuals at the age of four years, and found low correlation (0.49) among the four tested locations. They mention that clonal trials tend to present higher genotype $\mathrm{x}$ environment interaction than trials planted with progenies originated from seeds. Martinez et al. (2012) assessed an open pollinated progeny trial of $P$. taeda, planted in five locations and three site classes. They found high genetic correlation between the tested sites (0.71) and it allowed conducting a breeding program in one of the locations. Paludzyszyn Filho et al. (2001) also carried out trials with half-sib progenies of $P$. taeda in four locations. They found significant and complex genotype $\mathrm{x}$ environment interactions in the tested locations. They point out that parents' selection must be conducted to understand the specific needs of each location. However, they see this strategy as disadvantageous to breeding programs, given its costs with seeds' production.

The observed low genetic variability rate is following the degree of improvement of the assessed population, and it has confirmed the hypothesis that this population has already reached its limit. High selection intensity was likely used at the first breeding cycle due to the significant reduction in effective population size. Small effective population sizes imply in reducing genetic diversity and in increasing inbreeding in the following generation. Thus, when the aim is to go on with genetic breeding programs through several selection and combination cycles, it is important balancing the effective population size and genetic gains.

There are several studies about the ideal effective-population size for long-term genetic breeding programs, but it seems that the total of 30 is enough. According to Danusevicius and Lindigren (2005), a breeding population ranging from 30 to 70 individuals would take back the maximum benefit per reproduction cycle based on a long-term enhancement strategy. Based on Dvorak (2012), effective-population size of 30 individuals is enough to conserve most alleles presenting occurrence frequency higher than 5\%. Johnson et al. (2001) state that population size ranging from 30 to 50 individuals is enough to one single feature, if the aims of the selection are not changed. However, it is important to understand the concept differences between number of individuals in a population and the effective population size of such a population.

Controlled crossing is the strategy to increase population genetic variability. Intra-specific crossing between divergent genotypes leads to increased long-term population general genetic variability and, consequently, to increased ability to respond to selective pressure (RIUS and DARLING, 2014). The more divergent the parents, the greater the possibility of having variability in the generated segregating population and the greater the possibility of reorganizing the alleles based on new favorable combinations (MANFIO et al., 2012; SANTOS et al., 2016). Another important factor lies on the fact that depression caused by inbreeding can be removed by breeding after one generation (JOHNSON et al., 2001). However, it is essential highlighting that heterosis between divergent parents depends on the existence of dominance in character control and on the presence of divergence (FALCONER and MACKAY, 1996). Therefore, it is necessary carrying out diallelic tests to prove the occurrence of heterosis for the features of interest.

Thus, genetic breeding programs can be conducted with two selected populations if one considers the soil and climate conditions in the tested locations. One seed orchard to produce seeds for planting in less sloped topography in Rio Negrinho and Lages regions; and another seed orchard site presenting more sloping topography

FLORESTA, Curitiba, PR, v. 51, n. 1, p. 211-219, jan/mar 2021.

Ishibashi, V. et.al.

ISSN eletrônico 1982-4688

DOI: $10.5380 /$ rf.v51 i1. 68057 
Rio Negrinho region. Both seed orchards can be planted in Rio Negrinho to make the logistic applied to seeds production easier.

\section{CONCLUSIONS}

The performed analyses allowed concluding that:

- The $P$. taeda genetic material used in this study presented significant genotype $\mathrm{x}$ environment interaction for variable $\mathrm{DBH}$, in individuals at the age of nine years; therefore, it is recommended to divide the tested locations into two different breeding zones.

- A clonal seed orchard in each of the two breeding zones, with 50 genetically selected individuals and limited number of individuals per family, is the breeding strategy recommended to maintain genetic gain equilibrium and effective population size in advanced generations.

- Intraspecific-controlled crossing between divergent families can be used to increase heterosis and genetic variability in the assessed population.

\section{ACKNOWLEDGEMENT}

We are grateful to Conselho Nacional de Desenvolvimento Científico e Tecnológico (CNPq), Coordenação de Aperfeiçoamento de Pessoal de Nível Superior (CAPES) for the schollarship and to Valor Florestal for the financial, material and personal support for development of this research.

\section{REFERENCES}

ALVARES, C. A.; STAPE, J. L.; SENTElhas, P. C.; MORAES, G. de; LEONARDO, J.; SPAROVEK, G. Köppen's climate classification map for Brazil. Meteorologische Zeitschrift, v. 22, n. 6, p.711-728, 2013.

CORREIA, I.; ALÍA, R.; YAN, W.; DAVID. T.; AGUIAR, A.; ALMEIDA, M. H. Genotype $\times$ Environment interactions in Pinus pinaster at age 10 in a multienvironment trial in Portugal: a maximum likelihood approach. Annals of Forest Science, v. 67, n. 6, p. 612-612, 2010.

DANUSEVICIUS, D. e LINDGREN, D. Optimization of breeding population size for long-term breeding. Scandinavian journal of forest research. v. 20, n. 1, p. 18-25, 2005.

DIAS, P. C.; XAVIER, A.; RESENDE, M. D. V.; BARBOSA, M. H. P.; BIERNASKI, F. A.; ESTOPA, R. A. Genetic evaluation of Pinus taeda clones from somatic embryogenesis and their genotype $\mathrm{x}$ environment interaction. Crop Breeding and Applied Biotechnology, v. 18, n. 1, p. 55-64, 2018.

DVORAK, W. S. The strategic importance of applied tree conservation programs to the forest industry in South Africa. Southern Forests: a Journal of Forest Science, v. 74, n. 1, p. 1-6, 2012.

ELIAS, A. A.; ROBBINS, K. R.; DOERGE, R. W.; TUINSTRA, M. R. Half a century of studying genotypex environment interactions in plant breeding experiments. Crop Science, v. 56, n. 5, p. 2090-2105, 2016.

FALCONER, D. S. AND MACKAY, T. F. C. Introduction to quantitative genetics. 4th. ed. Essex: Longman, 1996.

GOMES, J. B. V.; BOGNOLA, I. A.; STOLLE, L.; SANTOS, P. E. T.; MAEDA, S.; SILVA, L. T. D. M.; BELLOTE, A. F. J.; CASTRO ANDRADE, G. Unidades de manejo para pinus: desenvolvimento e aplicação de metodologia em áreas de produção no oeste catarinense. Scientia Forestalis, v. 44, n. 109, p. 91-204, 2016.

HORST, T. Z.; DALMOLIN, R. S. D.; CATEN, A. T.; MOURA-BUENO, J. M.; CANCIAN, L. C.; PEDRON, F. D. A.; SCHENATO, R. B. Edaphic and topographic factors and their relationship with dendrometric variation of Pinus taeda L. in a high altitude subtropical climate. Revista Brasileira de Ciência do Solo, v. 42, p. 1-16, 2018.

INDÚSTRIA BRASILEIRA DE ÁRVORES (IBÁ) (2017) Relatório IBÁ 2017 ano base 2016. Brasília: IBÁ. 80 $\mathrm{p}$.

JOHNSON, R. A. N. D. Y.; CLAIR, B. S.; LIPOW, S. A. R. A. Genetic conservation in applied tree breeding programs. In In: Proceedings ITTO conference on in situ and ex situ conservation of commercial tropical trees, p. 215-230, 2001. 
MANFIO, C. E.; MOTOIKE, S. Y.; RESENDE, M. D. V.; SANTOS, C. E. M.; SATO, A. Y. Avaliação de progênies de macaúba na fase juvenil e estimativas de parâmetros genéticos e diversidade genética. Pesquisa Florestal Brasileira, v. 32, n. 69, p. 63-68, 2012.

MARTINEZ, D. T.; RESENDE, M. D. V.; COSTA, R. B.; HIGA, A. R.; SANTOS, G. A.; FIER, I. S. N. Estudo da interação genótipo $\mathrm{x}$ ambiente em progênies de Pinus taeda por meio da análise de parâmetros genéticos. Floresta, v. 42, n. 3, p. $539-$ 552, 2012.

PALUDZYSZYN FILHO, E.; MORA, A. L.; MAESTRI, R. Interação de Genótipos de Pinus taeda L. com locais no Sul-Sudeste do Brasil. Revista Cerne, v. 7, n. 1, p. 90-100, 2001.

RESENDE, M. D. V. Selegen-Reml/Blup: Sistema Estatístico e Seleção Genética Computadorizada via Modelos Lineares Mistos. Colombo: Embrapa Florestas, 2007, 361 p.

RESENDE, M. D. V. Genética quantitativa e de populações. Viçosa, MG: Suprema, 2015, 463 p.

RESENDE M. D. V. Software Selegen-REML/BLUP: a useful tool for plant breeding. Crop Breeding and Applied Biotechnology, v.16, p. 330-339, 2016.

RIUS, M. e DARLING, J. A. How important is intraspecific genetic admixture to the success of colonising populations? Trends in ecology \& evolution, v. 29, n. 4, p. 233-242, 2014.

RUIZ, C. L.; GABRIEL, J.; ZANATA, M.; TARLÉ PISSARA, T. C. Variabilidade espacial de atributos químicos do solo em áreas de pinus do instituto florestal de batatais-SP. Revista Brasileira de Tecnologia Aplicada nas Ciências Agrárias, v. 9, n. 2, 2016.

SANTOS, W.; ARAÚJO, E. G.; SOUZA, D. C. L.; DA SILVA, J. R.; RECCO, C. R. S. B.; DE MORAES, M. L. T.; AGUIAR, A. V. Divergência genética entre progênies de polinização aberta de Pinus caribaea var. hondurensis a partir de caracteres quantitativos. Pesquisa Florestal Brasileira, v. 36, n. 86, p. 127-133, 2016.

STURION, J. A. e RESENDE, M. D. V. Eficiência do delineamento experimental e capacidade de teste no melhoramento genético da erva-mate (Ilex paraguariensis St. Hil), Pesquisa Florestal Brasileira, v. $5^{\circ}$, p. 3-10, 2005 . 